\title{
Evaluation of the synergy between Schwanniomyces vanrijiae and propolis in the control of Penicillium digitatum on lemons
}

\author{
Kamal A. M. Abo-Elyousr ${ }^{1,2^{*}}$ (D) Adel D. Al-Qurashi ${ }^{1}$ and Najeeb M. Almasoudi ${ }^{1}$
}

\begin{abstract}
Background: Green mold disease on citrus caused by Penicillium digitatum is the most serious and destructive disease. It is causing $90 \%$ of production losses during post-harvest handling.

Results: In this study, the activity of seven yeast isolates from lemons against $P$. digitatum, a fungal pathogen that causes the green mold disease in lemons, was isolated and examined. In vitro experiments showed that isolate three significantly reduced pathogen growths and were later identified as Schwanniomyces vanrijiae. In addition, 3\% ethanolic extracts of propolis (EEP) caused a strong mycelial growth inhibition with inhibition halos of $1.4 \mathrm{~cm}$. The use of S. vanrijiae treatments to protect lemon fruits from green mold has been reported (55\%); however, reports describing the application of EEP are limited (40\%). Thus, the effectiveness of the combination of S. vanrijiae and 3\% EEP in an antagonistic mixture for protecting lemon fruits from $P$. digitatum was examined. EEP and S. vanrijiae treatments were applied alone and in combination in both in vitro and in vivo conditions. The combined application of 3\% EEP + S. vanrijiae on lemon fruits significantly reduced the severity and incidence of green mold (80 and 93.7\%, respectively) with much higher efficacy than either treatment alone. Lemon fruits treated with both S. vanrijiae and 3\% EEP showed increased levels of antioxidants, peroxidase (POD), polyphenol oxidase (PPO), and phenol than the untreated control.
\end{abstract}

Conclusion: The results indicated that the combination of S. vanrijiae $+3 \%$ EEP can strongly protect lemon fruits from green mold compared with the sole application of either bioagent.

Keywords: Penicillium digitatum, Lemon, Biocontrol, Antioxidants, Propolis, Synergy

\section{Background}

Citrus fruits are one of the most economically important fruits in Saudi Arabia and have additional worldwide importance, being a major source of vitamin $\mathrm{C}$ and carotenoids. The most serious postharvest diseases of lemons are the blue and green mold caused by Penicillium sp. (Wang et al. 2018), with the green mold disease caused

\footnotetext{
*Correspondence: kaaboelyousr@agr.au.edu.eg

'Department of Arid Land Agriculture, Faculty of Meteorology, Environment and Arid Land Agriculture, King Abdulaziz University, Jeddah 80208, Saudi Arabia ${ }^{2}$ Department of Plant Pathology, Faculty of Agriculture, University of Assiut, Assiut 71526, Egypt
}

by Penicillium digitatum being the most serious and destructive (Eckert and Ogawa 1988). It is responsible for 90\% production losses during postharvest handling (Bagy et al. 2020). P. digitatum enters mature citrus fruits through wounds; this results in the appearance of white fungal mycelia exhibiting green-colored growths. This disease then spreads throughout the fruit, resulting in changes in color, texture, and taste, and the development of a large olive-green surface surrounded by mycelial growth. Synthetic fungicides are the most common method for controlling these types of plant diseases due to their speed and efficacy (Palou et al. 2008). However,

\section{Springer Open}

(c) The Author(s). 2021 Open Access This article is licensed under a Creative Commons Attribution 4.0 International License, which permits use, sharing, adaptation, distribution and reproduction in any medium or format, as long as you give appropriate credit to the original author(s) and the source, provide a link to the Creative Commons licence, and indicate if changes were made. The images or other third party material in this article are included in the article's Creative Commons licence, unless indicated otherwise in a credit line to the material. If material is not included in the article's Creative Commons licence and your intended use is not permitted by statutory regulation or exceeds the permitted use, you will need to obtain permission directly from the copyright holder. To view a copy of this licence, visit http://creativecommons.org/licenses/by/4.0/. 
post-harvest disease control with synthetic fungicides has resulted in the evolution of resistant strains, environmental pollution, and harmful effects on human health. Therefore, other methods for disease control besides synthetic fungicides must be developed.

The best current alternative to synthetic fungicides is bioagents application (Parafati et al. 2015). Yeast antagonists, including Pichia guilliermondii, Clavispora lusitaniae, and Cryptococcus laurentii (Zhang et al. 2020), have been shown to repress the growth of $P$. digitatum and $P$. italicum that affect citrus fruits. However, the biocontrol performance of antagonistic microorganisms is less effective than conventional fungicides under semi commercial circumstances (Liu et al. 2013). The efficacy of such antagonists in controlling postharvest diseases should thus be enhanced (Mahunu et al. 2016).

Propolis is a natural product from honeybees that exhibits multiple biological activities and has recently been described as a health supplement suitable for consumers. Water and ethanolic extracts of propolis (EEP) showed antifungal, antibacterial, and antioxidant behavior (AboElyousr et al. 2017). The biological activities exhibited by and chemical compounds contained in propolis depend on the collection time, geographical distribution, and nearby plant species (Hegazi et al. 2014). Propolis is composed of approximately $10 \%$ essential oils, 30\% wax, $50 \%$ resin, $5 \%$ pollen, and $5 \%$ of other organic compounds (Falcao et al. 2010). Propolis has been used to delay fugal decay in different fruits and extend lifetimes of stored fruits (Ozdemir et al. 2010). In addition, 3\% EEP was used to reduce the decay of oranges caused by Penicillium spp. (El-Badawy et al. 2012), and 10\% EEP completely repressed Penicillium spp. mycelial growth on potato dextrose agar (PDA) (Ayhan et al. 2013).

The study on the combined application of yeast + propolis bioagents to control the green mold disease of lemon has not been conducted before. Thus, this study was undertaken to examine the in vitro antagonistic activity of S. vanrijiae and EEP alone and in combination against $P$. digitatum, the pathogen responsible for green mold of lemon fruits. Also, in vivo studies to test the efficacy of the combination on $P$. digitatum in lemon fruits were performed.

\section{Methods}

\section{Isolation and characterization of endophytic yeasts and green mold}

Samples of healthy and infected lemon fruits that showed typical symptoms of the green mold disease were collected from a storage house located in Jeddah, Saudi Arabia, and seven isolates of endophytic yeasts and $P$. digitatum were obtained. Green mold pathogens were morphologically identified based on mycelial growth, colony color, and spore structure as described by Kurtzman et al. (2000), with identities confirmed by ITS region sequencing.

\section{In vitro inhibition of $P$. digitatum by yeast}

The in vitro inhibition of $P$. digitatum by seven yeast isolates was tested. A loop containing 24-h-old yeast was horizontally streaked near the edges of PDA; dextrose, $20 \mathrm{~g}$; agar, $15 \mathrm{~g}$; potato, $200 \mathrm{~g}$ ) plates. A 5-mm mycelial plug of a 3-day-old $P$. digitatum colony grown on PDA was placed upside down on each streaked plates $3 \mathrm{~cm}$ from each streak. PDA plates containing only $P$. digitatum plugs were used as controls. Plates were incubated at $25{ }^{\circ} \mathrm{C}$ for 5 days, and the reduction in $P$. digitatum growth was calculated using the following formula:

$$
\mathrm{I} \%=(\mathrm{A}-\mathrm{B} / \mathrm{A}) \times 100
$$

Where $I \%$ is the percent mycelial growth inhibition, $A$ represents the growth diameter of the control, and $B$ represents the growth diameter $(\mathrm{cm})$ of the pathogen for each treatments. Each experiment was performed twice with four replicates per experiment. The yeast isolates that most significantly reduced $P$. digitatum mycelial growth were selected for additional experiments.

\section{Preparation of EEP}

EEP were prepared by grinding $200 \mathrm{~g}$ of frozen propolis that was placed for $3 \mathrm{~h}$ prior to grinding. For grinding, $69 \%$ ethanol was used with an extraction ratio of 3:1 ethanol/propolis, and mixtures were shaken for 2 days at $150 \mathrm{rpm}$. Extracts were centrifuged at $5000 \mathrm{rpm}$ for 10 min and filtered using filter paper. The resulting supernatant was collected and kept at room temperature for 3 days to allow for evaporation, and the remaining resin was collected for future use. To prepare 1, 2, and 3\% EEP solutions, equivalent weights of propolis were dissolved in the required volume of $70 \%$ ethanol. Then, EEP solutions were incubated in the refrigerator for further use Abdel-Rahim and Abo-Elyousr (2017).

\section{In vitro inhibitory activity of EEP}

To evaluate the in vitro inhibitory activity of EEP, conidia were collected from 1-week-old $P$. digitatum cultures grown on PDA plates incubated at $25{ }^{\circ} \mathrm{C}$. Briefly, spore suspensions were prepared by addling distilled water to growing colony plates to collect spores, the concentration of each spore suspension was adjusted to $10^{4}$ spore $/ \mathrm{mL}$, and $1 \mathrm{~mL}$ spore suspension was spread on the surface of a fresh PDA plate. Next, 0.5-cm-diameter wells were prepared in each plate in which $50 \mu \mathrm{L}$ of $1 \%, 2 \%$, or $3 \%$ EEP were poured, with $100 \mu \mathrm{L}$ SDW plus $3 \%$ ethanol poured into wells of the control plates. Plates were then incubated at $25^{\circ} \mathrm{C}$ for 5 days in the dark, and the inhibition zone $(\mathrm{cm})$ around each well was 
measured. Four replicates for each treatment were used, and the experiment was conducted twice.

\section{Molecular identification of bioagents}

The selected bioagents were identified by PCR analysis of their ITS regions, except for $P$. digitatum, was identified based on morphology. For PCR amplification, DNA was extracted from 24-h-old yeast cultures using a DNeasy plant extraction kit (Qiagen, CA, USA) according to the manufacturer's instructions. The primer pair ITS1 F (GCATCGATGAAGAACGCAGC) and ITS4 R (TCC TCC GCT TAT TGA TATGC) was used to amplify partial ITS gene sequences (White et al. 1990). Standard PCR was performed with reaction mixtures containing $20 \mu \mathrm{L}$ DNA template, $4 \mu \mathrm{L} 10 \mathrm{mM}$ dNTPs, 5 $\mu \mathrm{L} 5 \times$ PCR buffer, $2.5 \mathrm{mM} \mathrm{MgCl} 2,2.5 \mathrm{U}$ Taq polymerase (Promega), 25 pmol of each primer, and sterilized distilled water up to a final volume of $50 \mu \mathrm{L}$. Reactions were performed in a thermal cycler using the following conditions: initial denaturation at $94{ }^{\circ} \mathrm{C}$ for $3 \mathrm{~min}$, followed by 35 cycles consisting of $94{ }^{\circ} \mathrm{C}$ for $60 \mathrm{~s}, 55{ }^{\circ} \mathrm{C}$ for $60 \mathrm{~s}$, and $72{ }^{\circ} \mathrm{C}$ for $60 \mathrm{~s}$, followed by a final extension of $72{ }^{\circ} \mathrm{C}$ for $7 \mathrm{~min}$. PCR products $(10 \mu \mathrm{L}$ aliquots $)$ were then analyzed on $1 \%$ agarose gels run for 75 min in TAE buffer (Tris, $40 \mathrm{mM}$; sodium acetate, $20 \mathrm{mM}$; EDTA, 1 $\mathrm{mM}$; pH 7.2), with bands detected using a UV illuminator. Ribosomal ITS PCR products were identified based on their relative amounts of electrophoretic migration, then eluted from the gel, and purified using a purification kit (SolGent, Daejeon, South Korea), following the manufacturer's instructions. PCR products were confirmed by sequencing (SolGent). Partial sequences of PCR products were compared with the whole yeast genome sequence obtained from NCBI, and the isolated sequences were $100 \%$ identical to the sequence obtained from NCBI.

\section{In vitro effects of S. vanrijiae PHYTSV1 and EEP In vitro inhibitory activity}

To examine the in vitro inhibition of $P$. digitatum by EEP and $S$. vanrijiae, spore suspensions of $P$. digitatum were prepared from 3-day-old colonies by adding $5 \mathrm{~mL}$ distilled water to Petri plates containing $10^{4}$ spores $/ \mathrm{mL}$. The resulting spore suspension $(200 \mu \mathrm{L})$ was then spread over the surface of a PDA plate. After the suspension had been absorbed by the plate, $0.5-\mathrm{cm}$ punches were made into the agar and then filled with a $50-\mu \mathrm{L}$ mixture

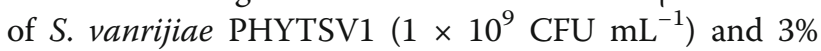
EEP (1:1). Next, plates were incubated at $27{ }^{\circ} \mathrm{C}$ for 5 days, and the reduction in mycelial growth $(I \%)$ was calculated. Four replicates were used per experiment, and each experiment was conducted twice.

\section{Effects on spore germination}

Effects of EEP and S. vanrijiae PHYTSV1 on spore germination were determined. Glass tubes were filled by potato dextrose broth (PDB), and $100 \mu \mathrm{L} P$. digitatum conidial suspension $\left(1 \times 10^{6}\right.$ conidia/mL $)$ was transferred to tubes containing S. vanrijiae PHYTSV1, EEP, or both. Control treatment tubes were also prepared with only PDB. Tubes were then incubated at $25{ }^{\circ} \mathrm{C}$ on a rotary shaker at $100 \mathrm{rpm}$ for $15 \mathrm{~h}$. To observe the germination rate for each treatment, at least 200 spores per replicate were examined under a microscope, and spore germination was determined using the criteria described by Elsherbiny et al. (2021). Germination inhibition of spores was calculated using the equation presented above. Three replicates were performed for each condition, and the experiment was conducted twice.

\section{In vivo activity of S. vanrijiae PHYTSV1 and EEP Preparation of pathogen and antagonist inoculum}

To prepare the inoculum, $P$. digitatum was transferred onto PDA plates and incubated at $25{ }^{\circ} \mathrm{C}$ for 7 days. After germination, $10 \mathrm{~mL}$ distilled water was added to each plate, and spores were scraped into solution using a sterilized bacterial rod. The spore suspension was then filtered through a layer of sterile muslin cloth. Using a hemocytometer, the concentration of the conidial suspension was counted and adjusted to $24 \times 10^{6} \mathrm{CFU} / \mathrm{mL}$ (Abdel-Rahim and Abo-Elyousr 2018). Erlenmeyer flasks were filled with $50 \mathrm{~mL}$ yeast malt broth medium, inoculated with $S$. vanrijiae PHYTSV1, and then incubated at $25{ }^{\circ} \mathrm{C}$ with shaking at $200 \times g$ for $48 \mathrm{~h}$. Tubes containing the resulting broth culture were then centrifuged at $6000 \mathrm{rpm}$ for $10 \mathrm{~min}$. The density of the re-suspended cells was then adjusted to $2 \times 10^{7}$ cells $/ \mathrm{mL}$ using a hemocytometer.

\section{Effects of S. vanrijiae and EEP on stored lemons}

Effects of S. vanrijiae PHYTSV1 and EEP on lemon fruits (Citrus limon L. Burm) were examined using protocols described by Sallam et al. (2012) with minor modifications. Briefly, healthy lemons of the seedless lime variety were purchased, and the surface was sterilized by dipping the fruits in $2 \% \mathrm{NaClO}$ for $2 \mathrm{~min}$. After surface sterilization, fruits were rinsed 3 times with sterilized distilled water and then placed on sterile filter paper to dry. Next, 2-mm-deep and 5-mm-wide wounds were made on the surface of the peel of each fruit in opposing directions. Each wound was covered with $50 \mu \mathrm{L}$ of $S$. vanrijiae $\left(1 \times 10^{9} \mathrm{CFU} / \mathrm{mL}\right), 3 \% \mathrm{EEP}$, or a $1: 1 \mathrm{v} / \mathrm{v} \mathrm{mix}-$ ture of each. For control samples, $20 \mu \mathrm{L}$ of sterile distilled water was added to each wound. Fruits were then allowed to sit at for $1 \mathrm{~h}$, and then, $20 \mu \mathrm{L}$ P. digitatum conidial suspension $\left(10^{4} \mathrm{CFU} / \mathrm{mL}\right)$ was injected into each fruit. The fruits were then incubated at $25{ }^{\circ} \mathrm{C}$ and 
90\% humidity for 7 days in $(25 \times 30 \mathrm{~cm})$ plastic boxes. The resulting lesion diameter on each fruit was measured according to Madbouly et al. (2020), and the disease incidence and severity determined as follows:

$\%$ Disease incidence $=($ No.of infected lemons $/$ Total no.of lemons $) \times 100$

Disease severity was evaluated using the following rating scale: $0=$ no infection observed; $1=$ a quarter of the fruit decayed; 2 = half the fruit decayed; $3=$ threequarters of the fruit decayed; and $4=$ the entire fruit decayed.

$\%$ Disease severity $=100 \times \Sigma($ No.of infected lemons $\times$ No.scale $)$

/Total no.of lemons $\times$ highness no.scale

Four replicates were used to perform each treatment with 20 lemons per treatment.

Effects of yeast and propolis on peroxidase (POD) and polyphenol oxidase (PPO) activities in lemon tissues

\section{Enzyme extraction}

To extract enzymes from lemons, $2 \mathrm{~g}$ of tissue from each fruit was collected. Tissues were placed in $20 \mathrm{mM}$ Tris- $\mathrm{HCl}$ buffer ( $\mathrm{pH}$ 7.2) and homogenized using a homogenizer. The homogenate was poured into glass tubes and centrifuged at $10,000 \mathrm{rpm}$ at $4{ }^{\circ} \mathrm{C}$ for $10 \mathrm{~min}$. Next, the supernatant was designated as crude extract and stored at -20 ${ }^{\circ} \mathrm{C}$ for later determination of PPO and POD activities.

\section{POD activity}

POD activity was measured according to Bereika et al. (2020) with some modifications. Each prepared reaction mixture was $1 \mathrm{~mL}$ in total and contained $0.25 \mathrm{~mL}(0.2$ M) sodium acetate ( $\mathrm{pH}$ 5.5), $8 \mu \mathrm{L}(0.97) \mathrm{M} \mathrm{H}_{2} \mathrm{O}_{2}, 0.08$ $\mathrm{mL}(0.5 \mathrm{M})$ guaiacol, and least amount of enzyme preparation. The change in absorbance at $470 \mathrm{~nm}$ reflecting guaiacol oxidation was then followed for 1 min using a spectrophotometer. Under standard assay conditions, the amount of enzyme that caused an increase in absorbance of at 1.0 O.D per min was defined as one unit of enzyme. Extraction buffer alone served as a blank reference sample. Three replicates were used for each treatment.

\section{PPO activity}

PPO activity was determined, following protocols from Batra and Kuhn (1975) using catechol as a substrate. A catechol solution $(20 \mathrm{mM})$ was prepared using $0.01 \mathrm{M}$ $\mathrm{Na}_{3} \mathrm{PO}_{4}$ (pH 6.8); then, $0.2 \mathrm{~mL}$ extract was added as quickly as possible to $2.8 \mathrm{~mL}$ catechol. Using a spectrophotometer, the change in absorbance at $400 \mathrm{~nm}$ was recorded for 2 min. An enzyme activity unit was defined as the amount of enzyme that caused an absorbance change of 0.1 in 1 min under standard assay conditions.
Extraction buffer alone served as a blank reference. Three replicates were measured for each treatment.

\section{Non-enzymatic assays \\ Sample preparation}

For flavonoid and phenolic compound extraction, $1.0 \mathrm{~g}$ sample was suspended in $10 \mathrm{~mL} 70 \%$ ethanol $(\mathrm{v} / \mathrm{v})$. The suspension was then placed at $30{ }^{\circ} \mathrm{C}$ on a shaker at 120 $\mathrm{rpm}$ for $2 \mathrm{~h}$ and then centrifuged at $1013 \times g$ for $5 \mathrm{~min}$. The resulting supernatant was used for further analysis.

\section{Total phenol content}

The total phenol content of each sample was measured by the method established by Malik and Singh (1980). Methanol extracts $(50 \mu \mathrm{L})$ of each sample or standard (gallic acid) were mixed with $850 \mu \mathrm{L}$ methanol, $100 \mu \mathrm{L}$ Folin-Ciocalteu reagent was added, and samples were left at room temperature for $5 \mathrm{~min}$. Next, samples were mixed with $500 \mu \mathrm{L} 20 \% \mathrm{Na}_{2} \mathrm{CO}_{3}$ and incubated at room temperature for $30 \mathrm{~min}$ to react. The absorbance of each sample at $750 \mathrm{~nm}$ was then measured, and the total phenol content was calculated based on a standard curve. The standard curve was prepared using gallic acid, and the phenol content in each extract was expressed as mg of gallic acid/g of fresh weight. Phenol content measurements were performed twice with three replicates.

\section{Total flavonoid content}

Using the modified colorimetric assay reported by Zhishen et al. (1999), flavonoid concentrations in each sample were determined. A $250-\mu \mathrm{L}$ aliquot of standard (catechin) or methanol extract was mixed with $75 \mu \mathrm{L} 5 \%$ $\mathrm{NaNO}_{2}$ and $1.25 \mathrm{~mL}$ sterile distilled water. The reaction mixture was left for $6 \mathrm{~min}$ and then mixed with $150 \mu \mathrm{L}$ $10 \% \mathrm{AlCl}_{3}, 0.5 \mathrm{~mL}(1 \mathrm{M}) \mathrm{NaOH}$, and $275 \mu \mathrm{L}$ sterile distilled water was added to solution. The absorbance of each solution was measured at $510 \mathrm{~nm}$, and the total flavonoid content was calculated using a standard curve. Known concentrations of catechin were used to generate a standard curve, and the results were described as $\mathrm{mg}$ of catechin equivalent/g.

\section{Statistical analysis}

Experimental data were analyzed using the statistical package Statistix (ver. 8.1), and two-way ANOVA was used. The least significant difference test at $P=0.05$ was performed for disease severity and disease incidence means to identify meaningful differences between the means of results of various treatments. Data were expressed as mean $\pm \mathrm{SE}$. 


\section{Results}

Isolation of endophytic yeasts and the causal pathogen of green mold of lemons

Fungal pathogens of green mold were isolated from infected lemons, while seven isolates of endophytic yeasts isolates were collected from healthy lemons.

In vitro antagonistic activity of yeast against $P$. digitatum All isolates were able to inhibit the mycelial growth of $P$. digitatum pathogens with varying levels of efficacy. Isolate 3 reduced $P$. digitatum growth by a significantly higher level than other isolates, with mycelium growth reductions of over $75 \%$ than the control (Table 1). Thus, three isolates were selected for further experiments.

\section{Molecular identification of bioagents and yeast species}

Yeast isolate 3 was identified as $S$. vanrijiae based on BLAST searches of the NCBI Nucleotide Collection Database for similar ITS sequences. A phylogenetic tree was also assembled using ITS sequences from $S$. vanrijiae and close homologues (Fig. 1) by using MEGAX. The ITS sequences of the pathogenic and yeast isolates we obtained have been added to the GenBank database under accession no. MT523046.

\section{In vitro inhibition of $P$. digitatum by EEP}

The in vitro antimicrobial effect of 1, 2, and 3\% EEP against $P$. digitatum was tested. The $3 \%$ EEP solution was the most effective one for inhibiting the mycelium growth of $P$. digitatum, with inhibition halos of $2.4 \mathrm{~cm}$ observed. Although lower, inhibitory activity was also observed for $1 \%$ and $2 \%$ EEP solutions, with inhibition halos of $1.3 \mathrm{~cm}$ and $1.4 \mathrm{~cm}$, respectively.

\section{In vitro inhibitory activity of S. vanrijiae PHYTSV1 and $3 \%$} EEP mixtures

The growth reduction of fungal pathogens was significantly higher when mixtures of $S$. vanrijiae and 3\% EEP

Table 1 Percentage of Penicillium digitatum growth inhibition caused by different yeast strain in vitro

\begin{tabular}{ll}
\hline Isolates no. & Inhibition zone (mm) \\
\hline 1 & $31.0 \pm 2.0 \mathrm{~b}$ \\
2 & $11.0 \pm 3.0 \mathrm{~d}$ \\
3 & $75.0 \pm 1.1 \mathrm{a}$ \\
4 & $22.0 \pm 2.0 \mathrm{C}$ \\
5 & $33.0 \pm 2.0 \mathrm{~b}$ \\
6 & $32.0 \pm 2.0 \mathrm{~b}$ \\
7 & $13.0 \pm 3.0 \mathrm{~d}$ \\
Control & $0.0 \pm 0.0 \mathrm{e}$ \\
\hline
\end{tabular}

Values in the column followed by different letters indicate significant differences among treatments according to lease significant differences test $(P$ $=0.05$ ) were used compared with the application of either component alone, with mixtures producing $3.3-\mathrm{cm}$ inhibition halos.

\section{Impact of the S. vanrijiae PHYTSV1 and 3\% EEP mixture on spore germination}

A mixture of $S$. vanrijiae and 3\% EEP caused significantly higher inhibition of $P$. digitatum spore germination $(P<0.05)$ than other individual treatments. The combination of $S$. vanrijiae $+3 \%$ EEP reduced $P$. digitatum spore germination by $80.5 \%$, while $3 \%$ EEP and $S$. vanrijiae caused 65 and $75 \%$ reductions in spore germination, respectively (Fig. 2).

\section{In vivo activity of S. vanrijiae PHYTSV1 and 3\% EEP}

The activities of S. vanrijiae PHYTSV1 and 3\% EEP were tested in vivo on lemon fruits. Artificial wounds were treated with $S$. vanrijiae PHYTSV1 and EEP either alone or as part of a mixture. After $1 \mathrm{~h}$ of incubation of wounds with $S$. vanrijiae PHYTSV1 and/or EEP, each wound was inoculated with a conidial suspension of $P$. digitatum. Results showed a significantly $(P 0.05)$ greater reduction in disease incidence on fruits treated with $S$. vanrijiae PHYTSV1 and EEP mixture compared with fruits treated with either component individually. Furthermore, disease severity was also reduced in fruits receiving combined treatments than in untreated control (Table 2).

Effect of S. vanrijiae PHYTSV1 and EEP alone and in combination on levels of defense-related enzymes, phenolic compounds, and flavonoids in lemons Effects on enzyme activity

During fruit storage, PO activity had significantly increased $(P<0.05)$ in all treated lemons compared with control lemons, 2 days post treatment. The maximum PO activity was reached 4 days post-treatment (Fig. 3). In addition, a similar pattern was observed for PPO activity, which began to decline 4 days post-treatment (Fig. 4).

\section{Total phenolic content}

The total phenol content was determined at multiple times post treatment (Fig. 5). The three tested treatments increased the total phenol content at all times, except day 1 . The total phenol content was highest in lemons treated with both S. vanrijiae PHYTSV1 and 3\% EEP, followed by lemons treated with either control and with untreated lemons containing the lowest amounts. After 4 days post-treatment, total phenolic levels began to decline.

\section{Total flavonoid content}

The total flavonoid content was measured up to 8 days post-treatment (Fig. 6). All treatments caused significant 
Trichosporon insectorum(LC498439.1)

Trichosporon asahii(KY928436.1)

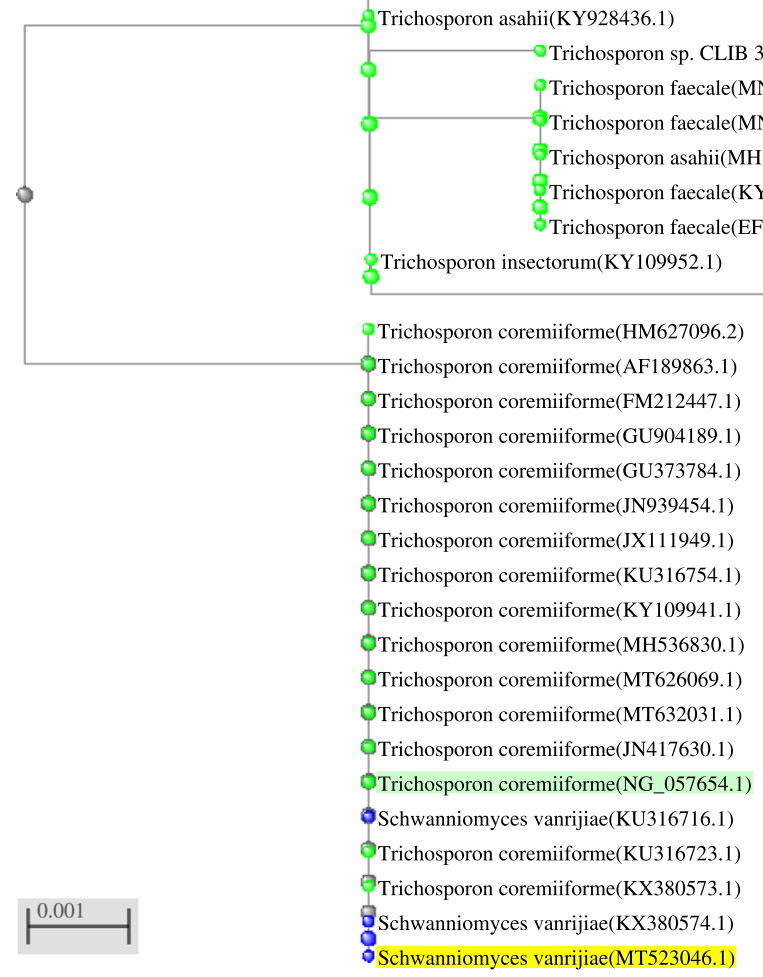

Fig. 1 Phylogenetic analysis of yeast isolate on ITS gene. This analysis was performed using the neighbor-joining method in BLAST pairwise alignments

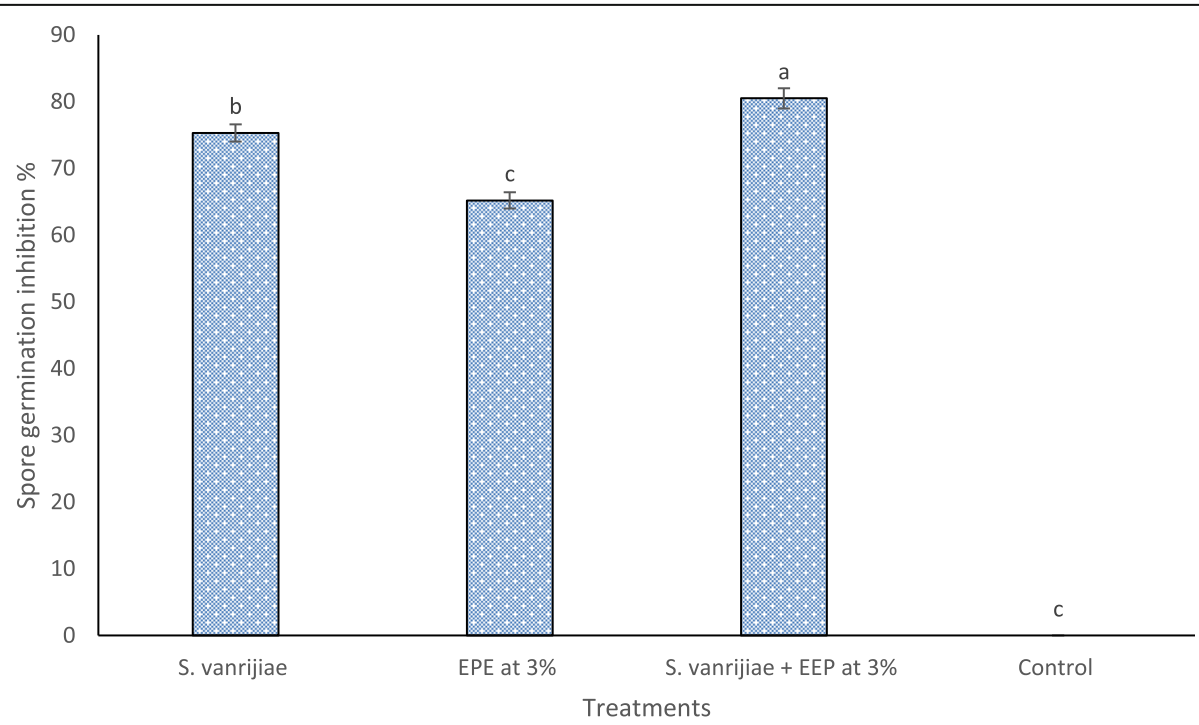

Fig. 2 Effect of S. vanrijiae, 3\% EPE, and mixture on spore germination. Values in the column followed by different letters indicate significant differences among treatments according to lease significant differences test $(P=0.05)$ 
Table 2 Effect of S. vanrijiae and ethanolic extract of propolis (EPE) alone and in combination on inhibiting Penicillium digitatum on lemon fruits 7 days post-incubated at $25^{\circ} \mathrm{C}$

\begin{tabular}{llll}
\hline Treatments & Incidence (\%) & Severity (\%) & Lesion diameter $(\mathbf{c m})$ \\
\hline S. vanrijiae & $45 \pm 0.6 \mathrm{c}$ & $10 \pm 0.3 \mathrm{c}$ & $1.0 \pm 0.03 \mathrm{c}$ \\
EPE & $60 \pm 0.6 \mathrm{~b}$ & $15 \pm 0.5 \mathrm{~b}$ & $1.9 \pm 0.02 \mathrm{~b}$ \\
S. vanrijiae \pm EPE & $20 \pm 1.1 \mathrm{~d}$ & $5 \pm 0.5 \mathrm{~d}$ & $0.5 \pm 0.04 \mathrm{~d}$ \\
Infected control & $100 \pm 0.5 \mathrm{a}$ & $80 \pm 0.2 \mathrm{a}$ & $5.0 \pm 0.02 \mathrm{a}$
\end{tabular}

Values in the column followed by different letters indicate significant differences among treatments according to lease significant differences test $(P$ $=0.05$ )

increases in the total flavonoid content than the controls. At 4 and 6 days post-treatment, flavonoid levels reached their maximum values, with flavonoid levels trending downward in lemons treated with a mixture of S. vanrijiae PHYTSV1 and EEP, EEP alone, and S. vanrijiae PHYTSV1 alone. After day 6, the flavonoid content began decreasing in all samples.

\section{Discussion}

In this study, seven yeast isolates from lemons had significant in vitro antifungal activity against $P$. digitatum, the causal pathogen of the green mold disease in citrus fruits. The antifungal potency of biocontrol agents likely arises due to the competition between antagonists and pathogens for nutrients, which can result in the production of antifungals, antibiotics, or mycoparasitism via cell wall hydrolysis (Madbouly et al. 2020). A previous study on the use of the yeast (P. guilliermondii) as treatment for green mold pathogens provides additional evidence that competition between pathogens and biocontrol antagonists for nutrients likely plays a key role in the biological control of P. digitatum (Winiewski et al. 1991). The production of metabolites by yeast may significantly affect the ability of other fungi to produce cell walldegrading enzymes and may hydrolyze the conidia of competing fungi (Li et al. 2019).

In the present study, 3\% EEP caused the highest reduction of mycelia growth of $P$. digitatum in vitro than 1 and $2 \%$ EEP, potentially due to the higher levels of antimicrobial and antioxidant activities of phenolic compounds resulting from increased EEP. Other researchers have reported a positive correlation between the antioxidant and antimicrobial characteristics of propolis and the polyphenols and flavonoid content of (Chaillou and Nazareno 2009). Moreover, previous work by Yang et al. (2009) showed that EEP contains more flavonoids and phenols than propolis extracts and exhibits more promising antifungal activity against $P$. italicum.

Spore germination and mycelial growth of $P$. digitatum was significantly reduced by $S$. vanrijiae and EEP. The discrepancy might be related to the levels of phenolic compounds in EEP or metabolites in S. vanrijiae (Agirman and Erten 2020).

Madbouly et al. (2020) reported that S. vanrijiae can be used to control disease in apple fruits under storage conditions. Using a separate metric for treatment success, Mattiuz et al. (2015) reported that propolis extracts can decrease the weight loss of citrus, apples, tomatoes,

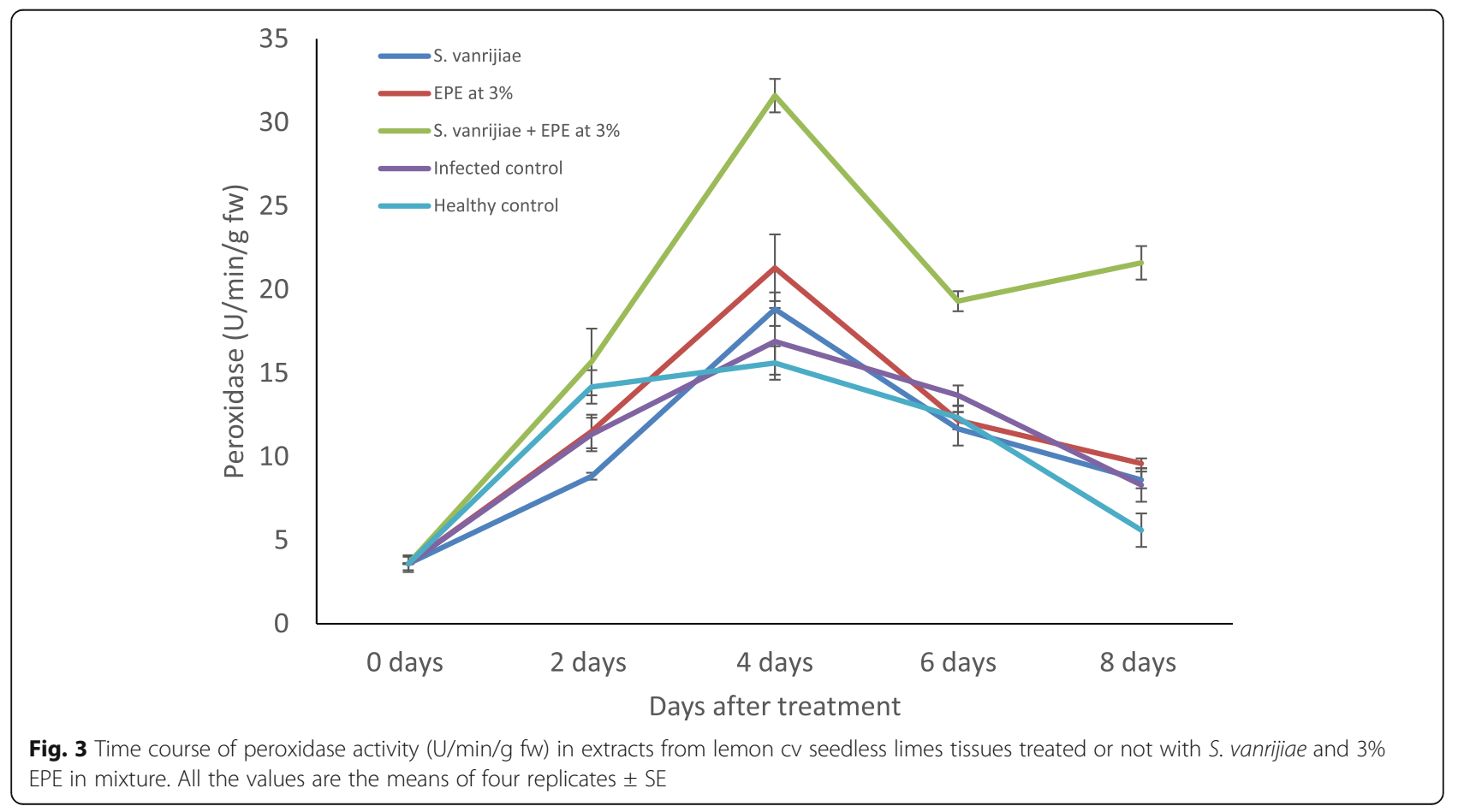




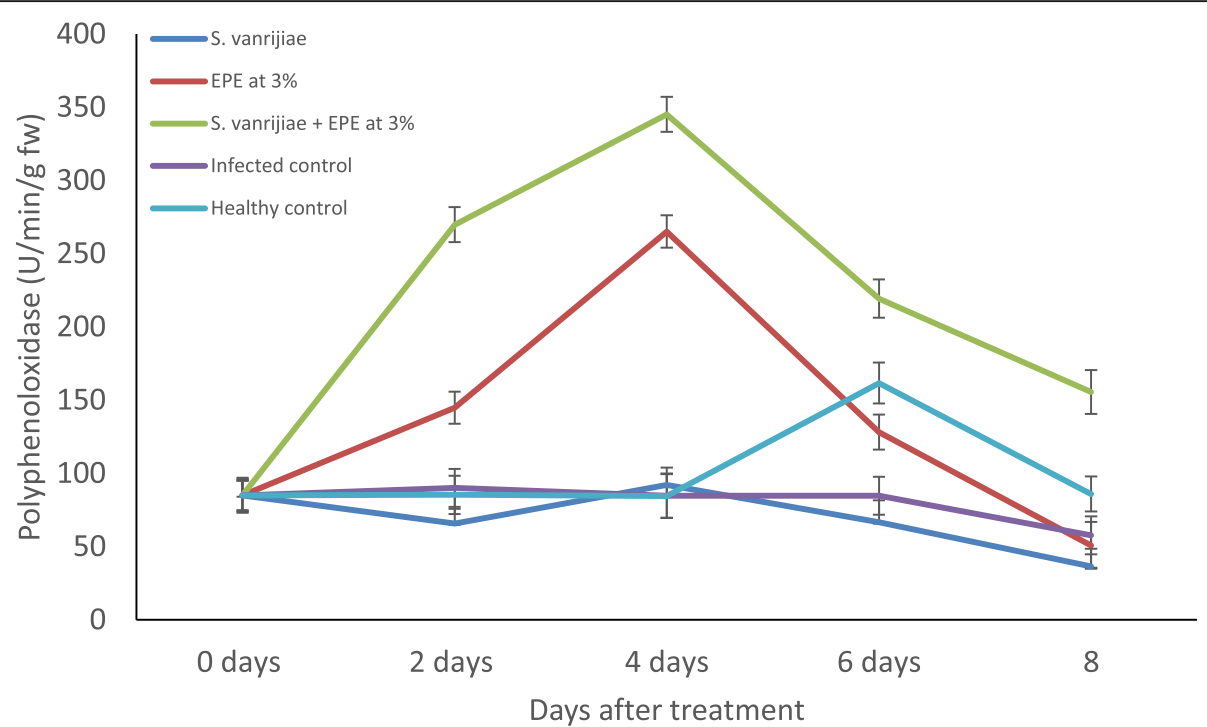

Fig. 4 Time course of polyphenoloxidase activity $(\mathrm{U} / \mathrm{min} / \mathrm{g} \mathrm{fw})$ in extracts from lemon cv seedless limes tissues treated or not with S. vanrijiae and $3 \%$ EPE in mixture. All the values are the means of four replicates \pm SE

and cherries during storage. When fruits are treated with propolis extracts, their surfaces develop coatings of beeswax, which can minimize water loss, gas exchange, and microbial infestations; extend shelf life; and maintain tissue firmness. In addition, the postharvest treatment of citrus fruits with propolis extracts was found to protect against natural disease incidence. For example, treatment with $1000 \mathrm{mg} / \mathrm{L}$ propolis reduced fruit decay from 30 to $13 \%$ after 22 days of storage. Moreover, numerous additional studies have described the broad activity of propolis against yeast, bacteria, and fungi, including phytopathogenic fungi such as Colletotrichum gloeosporioides, Botrytis, and P. italicum.

PO has a key role in lignification and suberization of host cell walls, which restricts disease development (Bereika et al. 2020). PO also helps strengthen plant cell walls at attachment sites by promoting lignification or cross-linking of specific proteins (Abo-Elyousr et al.

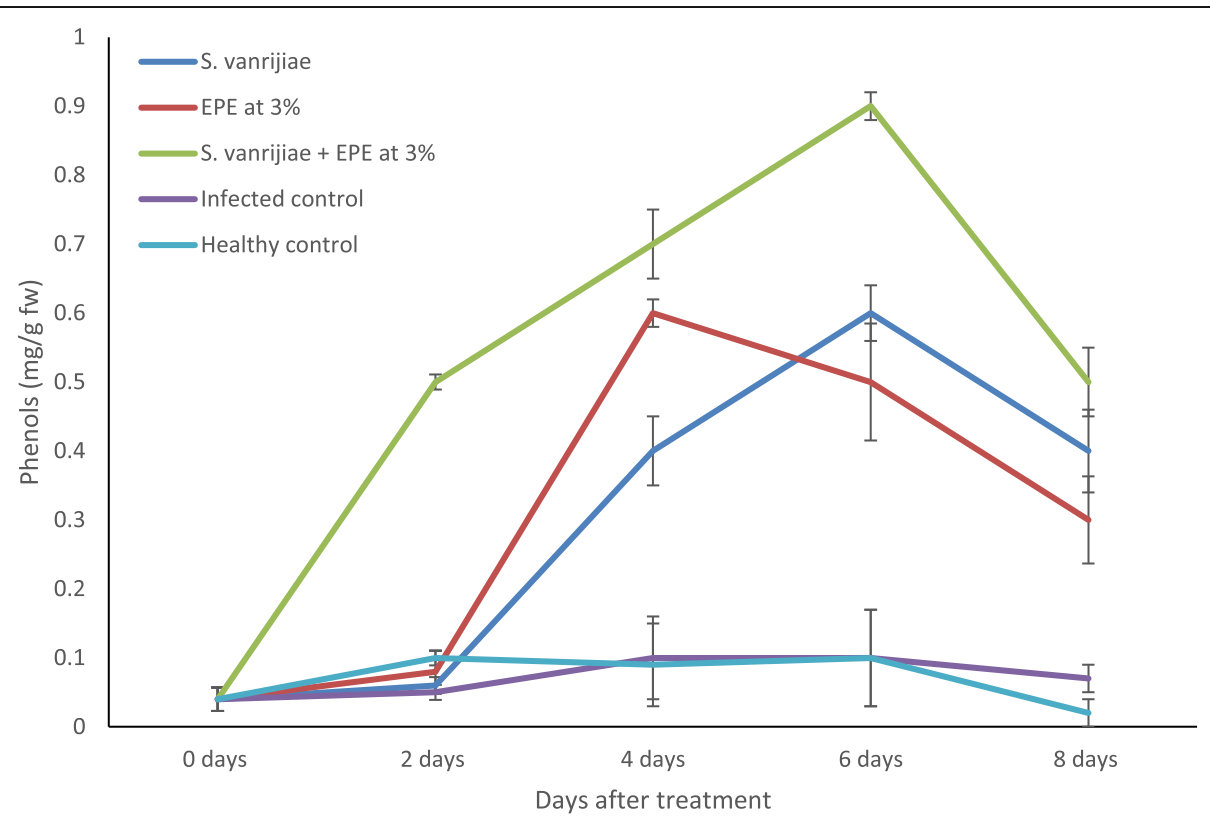

Fig. 5 Time course of phenol content (phenols ( $\mathrm{mg} / \mathrm{g} \mathrm{fw}$ ) in extracts from lemon cv seedless limes tissues treated or not with S. vanrijiae and 3\% EPE in mixture. All the values are the means of four replicates \pm SE 


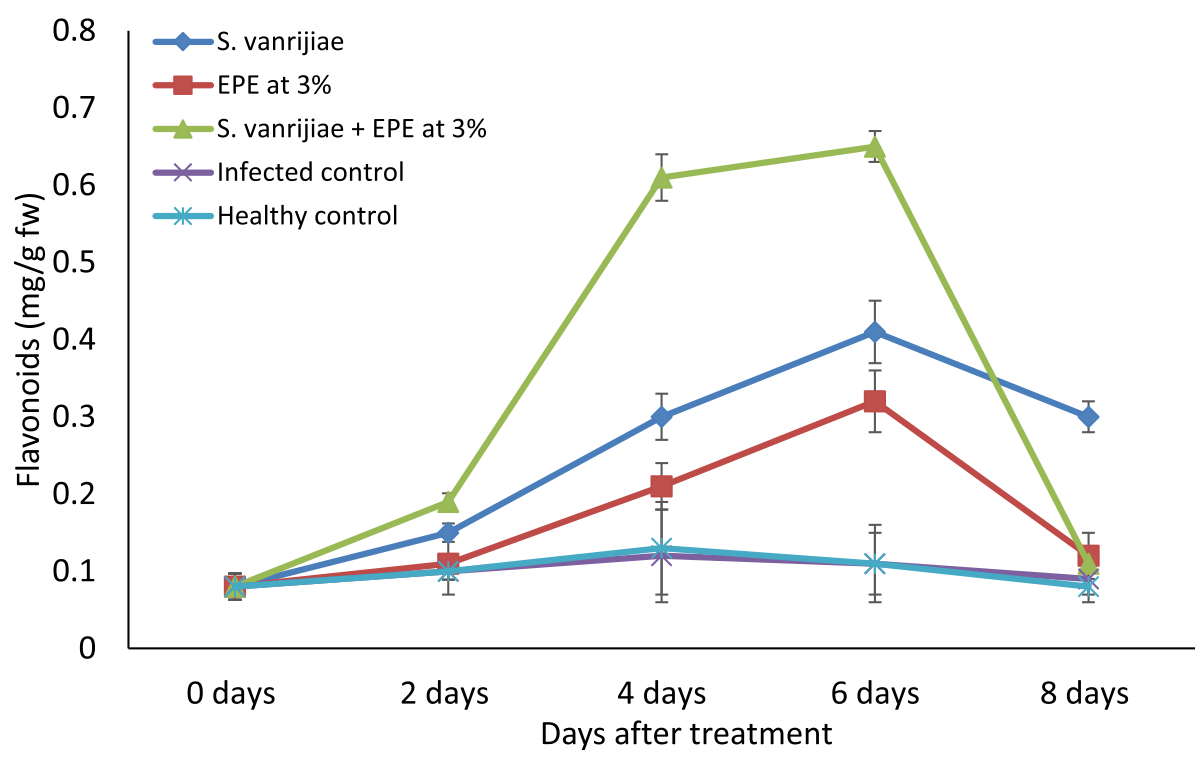

Fig. 6 Time course of flavonoids (mg/g fw) in extracts from lemon cv seedless limes tissues treated or not with S. vanrijiae and 3\% EPE in mixture. All the values are the means of four replicates \pm SE

2008). In the present experiments, PPO activity was higher in lemon fruits treated with yeast and EEP than in control fruits, with such activity increasing from 2 to 3 days after application.

In terms of total flavonoid and phenol content, this study demonstrated that a mixture of yeast and EEP caused a greater increase in phenol content and total flavonoids in lemons than application of either treatment on its own. These results are in agreement with previous studies that measured higher POD activity in apple fruits treated with Aureobasidium pullulans compared with control fruit (Youssef et al. 2020). S. vanrijiae and 3\% EEP application either alone or in combination exhibited strong in vitro reduction of $P$. digitatum radial growth and in vivo reductions in disease development on lemon fruits. Moreover, these treatments showed promise in conidia germination inhibition. Furthermore, the enhancement of PO and PPO activities, as well as levels of flavonoids and phenolic compounds, may have a direct relationship with the process by which yeast and EEP induce resistance against green mold in lemon fruits. Intensification of natural host resistance significantly correlated with augmentation of antioxidant systems.

\section{Abbreviations}

EPE: Ethanol propolis extracts; POD: Peroxidase activity; PPO: Polyphenol oxidase; LSD: Least significant difference

\section{Acknowledgements}

This project was funded by the Deanship of Scientific Research (DSR) at King Abdulaziz University, Jeddah, Saudi Arabia under grant no (G:24-155-1441). The authors, therefore, acknowledge with thanks DSR for technical and financial support. Also, We would like to thank Muhammad Imran, PhD. at the Arid Land Agriculture Department, Faculty of Meteorology, Environment and Arid Land Agriculture, King Abdulaziz University, for his indispensable technical support

\section{Authors' contributions}

All authors contributed equally in the manuscript. AKAM suggested the idea of the work and contributed to data curation and their validation as well as writing original draft. ADQ contributed to the formal analysis of the data. NMM contributed to the reviewing and editing the manuscript. All authors reviewed and approved the final version of the manuscript.

\section{Funding}

This project was funded by the Deanship of Scientific Research (DSR) at King AbdulAziz University, Jeddah, Saudi Arabia under grant no (G:24-155-1441).

Availability of data and materials

Not applicable

\section{Declarations}

Ethics approval and consent to participate

Not applicable. This manuscript is in accordance with the guide for authors available on the journal's website. Also, this work has not been published previously and is approved by all authors and host authorities

\section{Consent for publication}

Not applicable

\section{Competing interests}

The authors declare that they have no competing interests.

Received: 26 December 2020 Accepted: 11 April 2021

Published online: 17 April 2021

\section{References}

Abdel-Rahim IR, Abo-Elyousr KAM (2017) Using of endophytic Saccharomycopsis fibuligera and thyme oil for management of gray mold rot of guava fruits. Biol Cont 110:124-131. https://doi.org/10.1016/j.biocontrol.2017.04.014

Abdel-Rahim IR, Abo-Elyousr KAM (2018) Talaromyces pinophilus strain AUN-1 as a novel mycoparasite of Botrytis cinerea, the pathogen of onion scape and umbel blights. Microbiol Res 212-213:1-9. https://doi.org/10.1016/.micres.201 8.04 .004 
Abo-Elyousr KAM, Hussein MAM, Allam ADA, Hassan MHA (2008) Enhanced onion resistance against stemphylium leaf blight disease, caused by Stemphylium vesicarium, by di-potassium phosphate and benzothiadiazole treatments. Plant Pathol J 24:171-177. https://doi.org/10.5423/PPJ.2008.24.2.171

Abo-Elyousr KAM, Seleim MEA, El-Sharkawy RM, Bagy HMMK (2017) Effectiveness of Egyptian propolis on control of tomato bacterial wilt caused by Ralstonia solanacearum. J Plant Dise Protect 124(5):467-472. https://doi.org/10.1007/ s41348-017-0120-x

Agirman B, Erten H (2020) Biocontrol ability and action mechanisms of Aureobasidium pullulans GE17 and Meyerozyma guilliermondii KL3 against Penicillium digitatum DSM2750 and Penicillium expansum DSM62841 causing postharvest diseases. Yeast 37(9-10):437-448. https://doi.org/10.1002/yea.3501

Ayhan T, Mumcu AS, Tuylu AO, Sorkun K, Salih B (2013) Antifungal activity of propolis samples collected from different geographical regions of turkey against two Food-related molds, Aspergillus versicolor and Penicillium aurantiogriseum. GIDA 38:135-142. https://doi.org/10.5505/gida.2013.10820

Bagy HMMK, Badawy FMI, Abou-Zaid E, A.A, Badawy SM, Sallam MAN (2020) Control of green mold disease using chitosan and its effect on orange properties during cold storage. Arch Phytopathol Plant Protect:1-16. https:// doi.org/10.1080/03235408.2020.1847568

Batra G, Kuhn C (1975) Polyphenoloxidase and peroxidase activities associated with acquired resistance and its inhibition by 2-thiouracil in virus-infected soybean. Physiol Plant Pathol 5(3):239-248. https://doi.org/10.1016/0048-4 059(75)90090-9

Bereika FFM, Sallam NMA, Alamri SAM, Abo-Elyousr KAM, Hashem M, Mostafa YS (2020) Approving the biocontrol strategy of potato wilt caused by Ralstonia solanacearum on field scale using Enterobacter cloacae PS14 and Trichoderma asperellum T34. Egypt J Biol Pest Cont 30:61. https://doi.org/10.1186/s41938020-00262-9

Chaillou LL, Nazareno MA (2009) Bioactivity of propolis from Santiago del Estero, Argentina, related to their chemical composition. LWT Food Sci Technol 42(8):1422-1427. https://doi.org/10.1016/j.lwt.2009.03.002

Eckert JW, Ogawa JM (1988) The chemical control of postharvest diseases: deciduous fruits, berries, vegetables and root/tuber crops. Ann Revi Phytopathol 26(1):433-469. https://doi.org/10.1146/annurev.py.26.090188. 002245

El-Badawy HE, Baiea MH, Eman AA (2012) Efficacy of propolis and wax coatings in improving fruit quality of Washington navel orange under cold storage. Res J Agric Biol Sci 8:420-428

Elsherbiny E, Dawood HD, Nesreen AS (2021) Antifungal action and induction of resistance by $\beta$-aminobutyric acid against Penicillium digitatum to control green mold in orange fruit. Pesticide Biochem Physiol. 171:104721. https:// doi.org/10.1016/j.pestbp.2020.104721

Falcao SI, Vilas-Boas M, Estevinho LM, Barros C, Domingues MRM, Cardoso SM (2010) Phenolic characterization of Northeast Portuguese propolis: usual and unusual compounds. Anal Bioanal Chem 396(2):887-897. https://doi.org/10.1 007/s00216-009-3232-8

Hegazi A, Abdou AM, Abd-Allah F (2014) Egyptian propolis 11: its antimicrobial activity with comparison with different localities. Int J Curr Microbiol App Sci 3:530-538

Kurtzman C, Fell JW, Boekhout T (2000) The yeasts: A taxonomic study. 14(3).

Li J, Li H, Ji S, Chen T, Tian S, Qin G (2019) Enhancement of biocontrol efficacy of Cryptococcus laurentii by cinnamic acid against Penicillium italicum in citrus fruit. Postharvest Biol Technol 149:42-49. https://doi.org/10.1016/j.postha rvbio.2018.11.018

Liu J, Sui Y, Wisniewski M, Droby S, Liu Y (2013) Review: utilization of antagonistic yeasts to manage postharvest fungal diseases of fruit. Int J Food Microbiol 167(2):153-160. https://doi.org/10.1016/j.ijfoodmicro.2013.09.004

Madbouly A, Abo-Elyousr AM, Ismail MI (2020) Biocontrol of Monilinia fructigena the causal agent of brown rot of stored apple fruits using certain endophytic yeasts. Biol Cont 144C:104239. https://doi.org/10.1016/j.biocontrol.2020.104239

Mahunu GK, Hongyin Z, Qiya Y, Chaolan L, Xiangfeng Z (2016) Biological control of patulin by antagonistic yeast: a case study and possible model. Crit Rev Microbiol 42(4):643-655. https://doi.org/10.3109/1040841X.2015.1009823

Malik EP, Singh MB (1980) Plant Enzymology and Hittoenzymology, 1st edn. Kalyani Publishers, New Delhi, p 286

Mattiuz BH, Ducamp-Collin MN, Mattiuz CFM, Vigneault C, Marques KM, Sagoua W, Montet D (2015) Effect of propolis on postharvest control of anthracnose and qualityparameters of 'Kent' mango. Sci Hortic 184:160-168. https://doi. org/10.1016/j.scienta.2014.12.035
Ozdemir AE, Candir EE, Kaplankiran M, Soylu EM, Sahinler N, Gul A (2010) The effects of Ethanol-dissolved propolis on the storage of grapefruit cv. Star Ruby. Turk J Agric For 34:155-162. https://doi.org/10.3906/tar-0902-50

Palou L, Smilanick JL, Droby S (2008) Alternatives to conventional fungicides for the control of citrus postharvest green and blue moulds. Stewart Posthar Rev 4:1-16. https://doi.org/10.2212/spr.2008.2.2

Parafati L, Vitale A, Restuccia C, Cirvilleri G (2015) Biocontrol ability and action mechanism of food-isolated yeast strains against Botrytis cinerea causing post-harvest bunch rot of table grape. Food Microbiol 47:85-92. https://doi. org/10.1016/j.fm.2014.11.013

Sallam NMA, Badawy FM, Ibtesam A, Ibrahim R (2012) Biocontrol of green mold of orange using some yeasts strains and their effects on postharvest quality parameters. Int J Plant Pathol 3:14-24. https://doi.org/10.3923/ijpp.2012.14.24

Wang W, Liu S, Deng L, Ming J, Yao S, Zeng K (2018) Control of citrus postharvest green molds, blue molds, and sour rot by the cecropin a-melittin hybrid peptide BP21. Front Microbiol 9:2455. https://doi.org/10.3389/fmicb.2 018.02455

White TJ, Bruns T, Lee S, Tailor S (1990) Amplification and direct sequencing of fungal ribosomal RNA genes for phylogenetics. In: Innins MA, Gelfand DH, Sninsky JJ, White TJ (eds) PCR protocols. A guide to methods and applications. Academic Press, Inc., San Diego, pp 315-322. https://doi.org/1 0.1016/B978-0-12-372180-8.50042-1

Winiewski M, Biles C, Droby S, McLaughlin R, Wilson C, Chalutz E (1991) Mode of action of the postharvest biocontrol yeast, Pichia guilliermondii: I. Characterization of attachment to Botrytis cinerea. Physiol Mol Plant Pathol 39:245-258. https://doi.org/10.1016/0885-5765(91)90033-E

Yang SZ, Peng LT, Pan SY, Yao XL, Gao YL (2009) Antifungal activity of ethyl acetate extract of propolis against Penicillium italicum and its stability. Food Sci 30:87-90

Youssef K, Roberto SR, Tiepo AN, Constantino LV, de Resende JTV, Abo-Elyousr KAM (2020) Salt solution treatments trigger antioxidant defense response against gray mold disease in table grapes. J Fungi 6(3):179. https://doi.org/1 0.3390/jof6030179

Zhang H, Zhenga X, Chengxin F, Xia Y (2020) Postharvest biological control of gray mold rot of pear with Cryptococcus laurentii. Postharvest Biol Technol 35:79-86. https://doi.org/10.1016/j.postharvbio.2004.03.011

Zhishen J, Mengcheng T, Jianming W (1999) The determination of flavonoid contents in mulberry and their scavenging effects on superoxide radicals. Food Chem 64(4):555-559. https://doi.org/10.1016/S0308-8146(98)00102-2

\section{Publisher's Note}

Springer Nature remains neutral with regard to jurisdictional claims in published maps and institutional affiliations.

\section{Submit your manuscript to a SpringerOpen ${ }^{\circ}$ journal and benefit from:}

- Convenient online submission

- Rigorous peer review

- Open access: articles freely available online

- High visibility within the field

- Retaining the copyright to your article

Submit your next manuscript at $\boldsymbol{\nabla}$ springeropen.com 